\title{
BEHAVIOR OF LEISHMANIA MAJOR METACYCLIC PROMASTIGOTES DURING THE COURSE OF INFECTION AND IMMUNE RESPONSE DEVELOPMENT IN RESISTANT VERSUS SUSCEPTIBLE HOSTS
}

\author{
Regina Coeli Cunha Dórea ${ }^{1 *}$; Carlos Gomes Barboza-Filho ${ }^{1}$; Dayson Friaça Moreira ${ }^{1}$; Mirian Guirro ${ }^{1}$; \\ Ágtha de Alencar Muniz Chaves ${ }^{1}$; Ricardo José Dunder ${ }^{1}$; Elaine Amorim Soares ${ }^{2}$; \\ Vitório Santos-Júnior ${ }^{2}$; Wilma Spinosa ${ }^{2}$
}

${ }^{1}$ Departamento de Ciências Biológicas, Faculdade de Ciências e Letras, Universidade Estadual Paulista, Campus de Assis, Assis, SP, Brasil. ${ }^{2}$ Instituto Municipal de Ensino Superior de Assis, FEMA, Assis, SP, Brasil.

This paper corresponds to an "extended abstract" selected for oral presentation in the $22^{\text {nd }}$ Brazilian Congress of Microbiology, held in Florianópolis, SC, Brazil, in November 17-20, 2003

\begin{abstract}
Little is known on the epitopes derived from metacyclic promastigotes of Leishmania that are important on the regulation or destruction of the parasite, as targets of immune attack in the vertebrate host. In this study we investigated an alternative method to obtain metacyclic promasigotes of Leishmania major, as evaluated by the course of infection and delayed-type hipersensitivity (DTH) in resistant versus susceptible inbred mice. Non-infective (procyclic) promastigotes of L. major recently transformed from tissue amastigotes were attached to a negatively charged glass-wool column, whereas metacyclic promastigotes were not bound to columns and could be easily recovered. Optimal chromatography conditions were validated through statistical analyses. Parasite average yield from glass wool columns and promastigote viability were estimated by light microscopy. Metacyclic promastigotes yielded $43.5 \%$ to $57.5 \%$. Different patterns of cutaneous lesions were obtained in BALB/c (susceptible) and C57BL/6 (resistant) mice, the former with highly infective lesions induced by metacyclic promastigotes. DTH responses proved to be higher in groups of C57BL/6 mice which were infected with metacyclic promastigotes. These results indicate that the new method could be integrated with the investigation of metacyclogenesis of Leishmania in vivo.
\end{abstract}

Key words: Leishmania major, metacyclic promastigotes, metacyclogenesis, BALB/c mice, C57BL/6 mice.

\section{INTRODUCTION}

Protozoa belonging to the Leishmania genus, are a group of morphologically similar parasites causing a number of disease manifestations in humans, e.g., localized cutaneous leishmaniasis, mucocutaneous leishmaniasis and visceral leishmaniasis. Leishmania transforms from poorly infective procyclic promastigotes into highly infective metacyclic promastigotes in a process known as metacyclogenesis.
In nature, metacyclogenesis occurs in the insect vector (6). This transformation is accompanied by an increased ability to infect and survive in the vertebrate host, where the parasite is attacked by the host's immune system (4). Metacyclogenesis has also been shown to occur in axenic cultures of promastigotes. Morphological changes in size and shape, and length of flagellum were first associated with differentiation in the insect gut and in different phases of growth in culture (4). Later, the expression of molecules such as LPG and the surface

*Corresponding author. Mailing address: Departamento de Ciências Biológicas, Faculdade de Ciências e Letras, Universidade Estadual Paulista, UNESP, Campus de Assis. Avenida Dom Antonio 2.100. 19806-900, Assis, SP, Brasil. Tel.: (+5518) 3302-5856. Fax: (+5518) 3302-5849. E-mail: rdorea@assis.unesp.br 
protease gp63 were associated with this process $(2,5)$. These two molecules were observed to undergo several modifications as the promastigotes differentiated from procyclic to metacyclic forms $(1,7,8)$.

In the present work, we describe an alternative method to separate L. major subpopulations of promastigotes based on their affinity to a negatively charged glass-wool column.

\section{MATERIALS AND METHODS}

\section{Parasite \\ L. major strain MRHO/SU/59/NEALP.}

\section{Promastigote cell cultures}

Promastigotes were maintained by weekly subculture $\left(28^{\circ} \mathrm{C}\right)$ in liquid monophasic media consisting of BHI or RPMI 1640 supplemented with human urine $(2 \%, \mathrm{v} / \mathrm{v})$ and heat-inactivated fetal calf serum $(10 \%, \mathrm{v} / \mathrm{v})$.

\section{Purification of parasites}

A glass-wool based chromatography technique was used according to Pinho et al. (3). Briefly, glass wool (Merck, U.S.A.) was previously treated with sulphochromic solution for $2 \mathrm{~h}$ and thoroughly washed with distilled water and $0.15 \mathrm{M}$ phosphatebuffered saline (PBS). Small pieces of treated glass wool was firmly packed into $10-\mathrm{mL}$ plastic syringes using a glass rod. Columns were equilibrated with PBS containing 1\% (v/v) FCS. Stationary-phase promastigotes (SPP) were harvested from 5 to 7 day old cultures by centrifugation $\left(1000 \mathrm{x} g, 15 \mathrm{~min}, 4^{\circ} \mathrm{C}\right)$. A sample typically containing $5 \times 10^{7} \mathrm{SPP}$ was loaded to the column in a $1 \mathrm{~mL}$ volume of PBS. Flow rates were adjusted to $8 \mathrm{~mL} \mathrm{~h}^{-1}$ and two fractions of $7.5 \mathrm{~mL}$ each were eluted with PBS-FCS at room temperature. Viability, as well as bound or eluted promastigotes/total parasite ratio were determined by microscopic examination.

\section{Experimental procedures}

Two groups of female C57BL/6 mice and two groups of BALB/c mice (CEMIB, Fundação André Tosello, Campinas-SP, Brazil), weighing 10 to $12 \mathrm{~g}$ each, were injected s.c. at the base of the tail with either $1 \times 10^{6}$ bound promastigotes or an equivalent amount of eluted promastigotes. A control group of each mouse strain was injected with $1 \times 10^{6}$ non-separated SPP. For DTH reactions, a similar experimental design was used, except that mice were injected 21 to 30 days previously with column-processed parasites. An eliciting dose of $2.5 \times 10^{6}$ formalin-fixed promastigotes in $50 \mu \mathrm{L}$ PBS was injected into a metatarsal pad of the tensed plantar surface of the left hind footpad of infected and uninfected mice, and PBS was inoculated in the contralateral footpad. DTH results were measured using a spring-loaded dial gauge micrometer (Mitutoyo, Japan) at 4h, $12 \mathrm{~h}, 24 \mathrm{~h}, 48 \mathrm{~h}$ and $72 \mathrm{~h}$ after inoculation of antigen into the footpad. The net extent of swelling in the antigen-challenged footpad was calculated by subtracting the thickness of the control footpad from that of the antigen-injected footpad.

\section{RESULTS AND DISCUSSION}

We first studied the conditions that would lead us to obtain larger yields of metacyclic promastigotes of $L$. major by means of a standard chromatography technique, which had been previously used to purify trypomastigotes from a mixed Trypanosoma cruzi population grown in axenic medium (3). Optimal conditions included a neutral $\mathrm{pH}$ (7.2), an inoculum size of 4 to $6 \times 10^{7}$ early stationary phase promastigotes and 1.3 $\mathrm{g}$ of glass wool cut into small pieces wih a pair of scissors. Irrespective of the number of subpassages in vitro, those conditions proved to be satisfactory to yield as much as 43.5 to $57.5 \%$ metacyclic promastigotes (Fig. 1) and enabled us to statistically validate the method (Table 1).

In a typical experiment, cells adherent to the glass wool would be sometimes duplicating and not rarely have a slender body, and a medium-size flagellum, by which they would stick to glass refringent fragments, whereas parasites recovered from the eluting fractions often presented a short body and a long flagellum at approximately 1:3 to 1:4 ratio (Fig. 1).

To further investigate the efficiency of the method, bound cells and unbound promastigotes were used to infect groups of inbred mice, well-known for their susceptibility or resistance to L. major. Their pattern of lesion development, as well as the in vivo cellular immune response, as measured by DTH reaction to leishmanial antigens were compared to that of a control group of mice injected with a mixed population of stationary phase parasites. When compared to mice injected with bound parasites, the group of animals which were injected with eluted parasites showed higher numbers of ulcerating lesions in BALB/c strain than in C57BL/6 mice. This was noted mainly on weeks 18, 21 and 24 post-infection (Fig. 2).

As it is shown in Table 2, at early stages of infection, resistant C57BL/6 mice developed higher levels of DTH than susceptible

Table 1. Statistical analysis of glass-wool chromatography ${ }^{1}$ used for metacyclic promastigotes purification of L. major.

\begin{tabular}{|c|c|c|c|c|c|c|}
\hline $\begin{array}{c}\text { Analysis of } \\
\text { variance }\end{array}$ & Dof $^{2}$ & $\mathbf{M S}^{3}$ & F-ratio & P-value & \multicolumn{2}{|c|}{ Tukey analysis } \\
\hline & & & & & Species & $\%^{4}$ \\
\hline & 02 & 1875.5 & 22.97 & 0.00003 & L. major & 48.9 \\
\hline & 24 & 81.6 & & & L. amc & 71.7 \\
\hline Total & 06 & 1957.1 & & & L. braziliensis & 42.4 \\
\hline
\end{tabular}

${ }^{1}$ Chromatography conditions to the three Leishmania species were set to $1.3 \mathrm{~g}$ of glass wool and sample size of $5 \times 10^{7}$ stationary phase promastigotes; ${ }^{2}$ Degrees of freedom; ${ }^{3}$ mean square; ${ }^{4}$ average yield. 

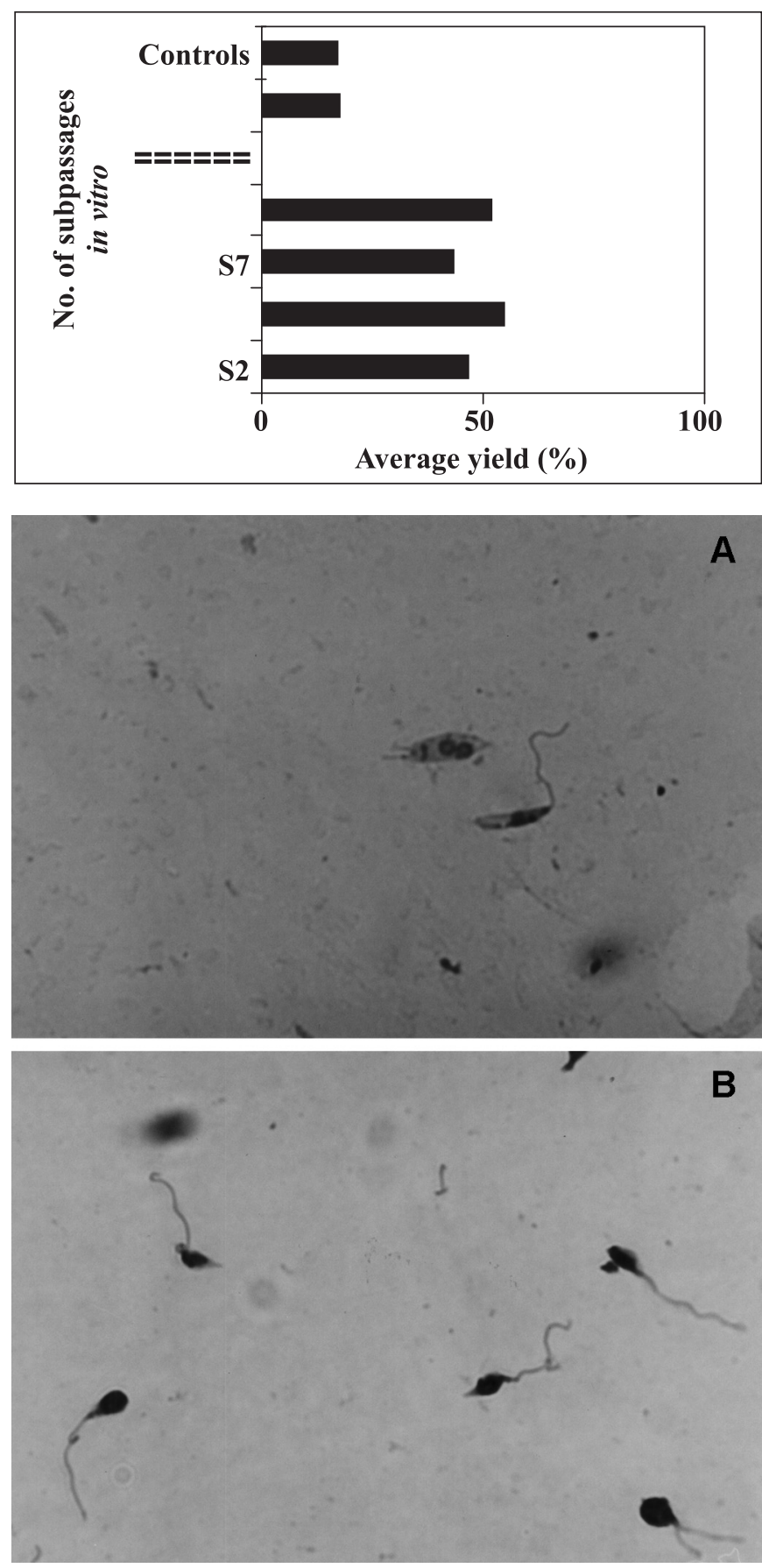

Figure 1. Top: average yield (\%) of eluted promastigotes after purification on a glass-wool column. S2 to S7 refer to the number of passages in culture medium of stationary-phase promastigotes. Controls are parasites derived from logarithmicphase culures. Bottom: micrographs obtained after parasite purification on a glass-wool column. (A) parasites attached to a fragment recovered from a glass-wool column; (B) parasites eluted after chromatography through a glass-wool column. X 400, Giemsa stain.
Table 2. Comparison of DTH responses in BALB/c and C57BL/ 6 mice infected with $1 \times 10^{6}$ stationary phase promastigotes of L.major after glass-wool chromatography.

\begin{tabular}{lcc}
\hline \multirow{2}{*}{$\begin{array}{c}\text { Groups of mice infected } \\
\text { with }\end{array}$} & \multicolumn{2}{c}{ No. of mice with } \\
\cline { 2 - 3 } & $\begin{array}{c}\text { Positive } \\
\text { DTH/total } \\
\text { number tested }\end{array}$ & $\begin{array}{c}\text { DTH } \\
\left(\mathbf{m m ~ x ~ 1 0} \mathbf{~ 1 0}^{-2}\right)\end{array}$ \\
\hline BALB/c mice & $1 / 7$ & $9.5 \pm 2.6$ \\
Bound parasites & $1 / 6$ & $4.1 \pm 6.6$ \\
Eluted parasites & $1 / 6$ & $6.6 \pm 7.9$ \\
Control (non-separated) & $1 / 6$ & $4.5 \pm 4.6$ \\
Control (uninfected) & & \\
\hline C57BL/6 mice & $4 / 6$ & $18.0 \pm 15.7$ \\
Bound parasites & $3 / 6$ & $15.0 \pm 13.9$ \\
Eluted parasites & $1 / 6$ & $5.6 \pm 6.9$ \\
Control (non-separated) & $1 / 6$ & $2.5 \pm 5.2$ \\
Control (uninfected) & & \\
\hline
\end{tabular}

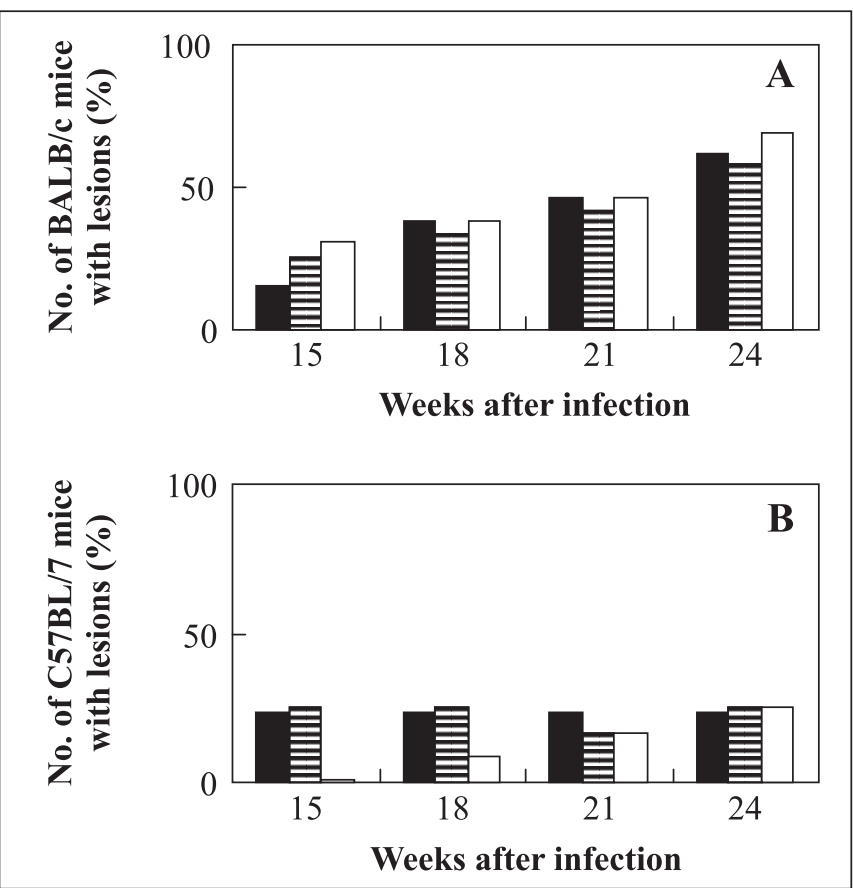

Figure 2. The course of L. major infection in BALB/c (A) and C57BL/6 (B) mice. Represented groups are PC (infected with eluted parasites; in black), $\mathrm{C}$ (infected with parasites bound to the glass-wool column; in black and white) and the control group, M (infected with non-separated SPP; in white). Data are expressed as percentage of mice with visible lesions per group ( $\mathrm{n} £ 15$ mice).

BALB/c mice, when injected with either bound or unbound cells. This was reflected in the intensity of DTH responses and, to some extent, in the number of mice with a positive DTH reaction. 
The enrichment of metacyclic L. major promastigotes obtained after elution from glass wool columns combined with the results from in vivo experiments, clearly show that glass wool columns are efficient in the purification of metacyclic promastigotes and may contribute to the investigation of metacyclogenesis of Leishmania parasites in vivo.

\section{ACKNOWLEDGEMENTS}

This work was supported by Fundação para o Desenvolvimento da UNESP, FUNDUNESP (Processo N ${ }^{\circ}$ 515/ 2002-DFP).

\section{RESUMO}

\section{Comportamento de promastigoteas metacíclicos de Leishmania major durante o curso da infecção e da resposta imune em hospedeiros resistentes versus suscetíveis}

Pouco se conhece sobre os epítopos derivados de promastigotas metacíclicos de Leishmania que são importantes para a regulação ou destruição do parasita, como alvos de ação imunológica no hospedeiro vertebrado. Neste estudo, nós investigamos um método alternativo para obter promastigotas metacíclicos de Leishmania major, pela avaliação do curso da infecção e reação de hipersensibilidade do tipo retardado (HTR) em hospedeiros resistentes e susceptíveis. Promastigotas nãoinfectantes (procíclicos) de L. major, recentemente isolados de amastigotas, foram selecionados pela adesão a colunas de lã de vidro negativamente carregadas, enquanto que promastigotas metacíclicos não se aderem à coluna e podem ser recuperados com facilidade. Condições ótimas de cromatografia foram validadas por análise estatística. $\mathrm{O}$ rendimento médio de parasitas obtidos após separação em colunas de lã de vidro e a viabilidade dos promastigotas foram estimados por microscopia óptica. Os promastigotas metacíclicos tiveram um rendimento médio de 43,5\% a 57,5\%. Camundongos BALB/c (susceptíveis) e camundongos C57BL/6 (resistentes) apresentaram padrões distintos de lesões cutâneas, os primeiros com lesões mais agressivas, induzidas por promastigotas metacíclicos. As respostas à reação de HTR foram maiores nos grupos de camundongos C57BL/6, submetidos à infecção com promastigotas metacíclicos. Estes resultados indicam que o novo método poderia ser integrado aos protocolos existentes para estudar a metaciclogênese de parasitas do gênero Leishmania in vivo.

Palavras-chave: Leishmania major, promastigotas metacíclicos, metaciclogênese, camundongos BALB/c, camundongos C57BL/6.

\section{REFERENCES}

1. Dobson, D.E.; Scholtes; L.D.; Valdez, K.E.; Sullivan D.R.; Mengeling, B.J.; Cilmi, S.; Turco, S.J.; Beverley, S.M. Functional identification of galactosyltransferases (SCGs) required for species-specific modifications in lipophosphoglycan adhesin controlling L. majorsandfly interactions. J. Biol. Chem., 278(18):15523-15531, 2003.

2. McConville, M.J.; Turco, S.J.; Ferguson, M.A.J.; Sacks, D.L. Developmental modification of lipophosphoglycan during the diferentiation of Leishmania major promastigotes to an infectious stage. EMBO J., 11:3593-3600, 1992.

3. Pinho, R.T.; Dutra, H.S.; De Simone, S.G.; Pontes de Carvalho, L.C. A glass-wool based method for purifying Trypanosoma cruzy tripomastigotes and identification of an epimastigotes-especific glassadherent surface peptide. Acta Tropica, 50:29-38, 1992.

4. Sacks, D.L. Metacyclogenesis in Leishmania promastigotes. Exp. Parasitol., 69:100-103, 1989.

5. Sacks, D.L.; Brodin, T.N.; Turco, S.J. Developmental modification of the lypophosphoglycan from L. major promastigotes during metacyclogenesis. Mol. Biochem. Parasitol., 40:225-234, 1990.

6. Sacks, D.L.; Perkins, P. Development of infective stage Leishmania promastigotes within phlebotomine sandflies. Am. J. Trop. Med. Hyg., 34:456-459, 1985.

7. Sacks, D.L.; Pimenta, P.F.P.; McConville, M.J., Scheneider, P.; Turco, S. Stage-specific binding of Leishmania donovani to the sand fly midgut is regulated by conformational changes in the abundant surface lipophosphoglycan. J. Exp. Med., 181:685-697, 1995.

8. Späth, G.F.; Epstein, L.; Leader, B.; Singer, S.M.; Avila, H.A.; Turco, S.J.; Beverley, S.M. Lipophosphoglycan is a virulence factor distinct from related glycoconjugates in the protozoan parasite Leishmania major. Proc. Natl. Acad. Sci. (USA), 97:9258-9263, 2000. 